\title{
Rehabilitation of Cognitive Disorder After Temporal Lobe Epilepsy Surgery: Proposal for a Protocol
}

\author{
Temporal Lob Epilepsilerinde Cerrahi Sonrası Bilişsel \\ Bozuklukların Rehabilitasyonu: Bir Protokol Önerisi
}

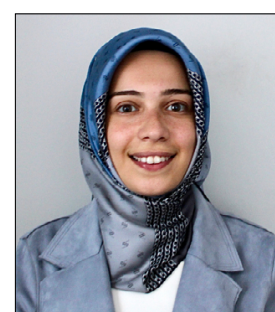

Dr. Mevhibe SARICAOĞLU

\section{(1) Mevhibe SARICAOĞLU, ${ }^{1}$ (1) Özden ERKAN OĞUL, ${ }^{2}$ (1) Çiğdem ÖZKARA, ${ }^{3}$ (1) Lütfü HANOĞLU ${ }^{4}$}

\author{
'Program of Electroneurophysiology, İstanbul Medipol University School of Vocational, İstanbul, Turkey \\ ${ }^{2}$ Department of Occupational Therapy, İstanbul Medipol University Faculty of Health Sciences, İstanbul, Turkey \\ ${ }^{3}$ Department of Neurology, İstanbul University-Cerrahpaşa Cerrahpaşa Faculty of Medicine, İstanbul, Turkey \\ ${ }^{4}$ Department of Neurology, İstanbul Medipol University Faculty of Medicine, İstanbul, Turkey
}

\begin{abstract}
Summary
Objectives: Surgical intervention is a crucial and effective treatment option for patients with temporal lobe epilepsy whose seizures are not under control. However, there is a possibility that surgical intervention may have a negative effect on cognitive functions. Cognitive rehabilitation is a treatment option that has been recently investigated for various neurocognitive problems. This study proposes a protocol for the rehabilitation of the cognitive dysfunctions after temporal lobe epilepsy surgery.

Methods: To overcome the cognitive deficits that occurred after surgery, a six-step program was developed, which included the compensatory and adaptation strategies and memory and executive functions. This program was performed after epilepsy surgery in two patients who were evaluated with neuropsychometric test battery.

Results: Cognitive rehabilitation program had a significant and positive effect on the neuropsychometric test results in two epilepsy patients who had postoperative attention, memory and executive function problems.

Discussion: In the postoperative period, patients with temporal lobe epilepsy may be able to recover from cognitive disorders with an effective $C R$ program. Although our results were obtained only with two patients, they suggest that cognitive rehabilitation had a significant and positive effect on epilepsy patients with postoperative attention, memory and executive function problems. However, the onset of the rehabilitation before or after surgery, the duration and the content of the rehabilitation are controversial issues.

Conclusion: Future studies should show evidence basis of the standardized rehabilitation program for patients after epilepsy surgery, and the short and long-term effects of the rehabilitation with larger participants.
\end{abstract}

Keywords: Cognitive rehabilitation; epilepsy; temporal lobe surgery.

\section{Özet}

Amaç: Nöbet kontrolü sağlanamayan temporal lob epilepsi hastaları için cerrahi müdahale önemli ve etkili bir tedavi seçeneğidir. Ancak cerrahi müdahalenin bilişsel fonksiyonlar üzerinde olumsuz etki oluşturma ihtimali vardır. Son zamanlarda bilişsel rehabilitasyon, çeşitli nörobilişsel problemler için araştııılan bir tedavi seçeneğidir. Bu çalışmanın amacı, temporal lob epilepsi cerrahisi sonrası bilişsel işlevlerdeki bozulmanın rehabilitasyonuna yönelik bir protokol önerisi sunmaktır.

Gereç ve Yöntem: Cerrahi müdahale sonrası meydana gelmiş bilişsel bozuklukların üstesinden gelmek için kompansatuar ve adaptasyon stratejilerini içeren, bellek ve yürütücü fonksiyonları geliștiren, altı adımdan oluşan bir program düzenlendi. Nöropsikometrik test bataryası ile ayrıntılı şekilde değerlendirilen iki hastaya epilepsi cerrahisi sonrası bu program uygulandı.

Bulgular: Ameliyat sonrası dikkat, bellek ve yürütücü işlev sorunları yaşayan iki epilepsi hastasında, kognitif rehabilitasyon programının nöropsikolometrik test sonuçlarına göre anlamlı ve olumlu etkisi olduğu görüldü.

Sonuç: Ameliyat sonrası dönemde temporal lob epilepsi hastalarının yaşadıkları/yaşayacakları bilişsel bozuklukların iyileşmesi etkin bir BR programı ile mümkün olabilir. Her ne kadar sonuçlarımız iki hasta ile elde edilmiş olsa da ameliyat sonrası dikkat, bellek ve yürütücü işlev sorunları yaşayan epilepsi hastalarında kognitif rehabilitasyonun anlamlı ve olumlu etkisi olduğunu gösterdi. Rehabilitasyonun bilişsel yetenekler üzerinde olumlu bir etkisi vardır ancak rehabilitasyonun cerrahiden önce veya sonra başlaması, rehabilitasyon süresi ve içeriği tartışmalıdır. Gelecekteki çalışmalar cerrahi sonrası epilepsi hastaları için standartlaştırılmış rehabilitasyon programını, rehabilitasyonun kısa ve uzun dönem etkilerini daha büyük katılımcılar ile kanıta dayalı şekilde göstermelidir.

Anahtar sözcükler: Bilişsel rehabilitasyon; epilepsi; temporal lob cerrahisi.

Submitted (Geliş): 19.09.2019

Accepted (Kabul) : 10.12.2019 


\section{Introduction}

Temporal lobe epilepsy (TLE) accounts for $30-35 \%$ of all epilepsies. ${ }^{[1]}$ Seizure control is not achieved in $75 \%$ of the TLE patients despite medical treatment using antiepileptic drugs ${ }^{[2]}$ Epilepsy surgery is an important and effective treatment option for these patients. Successful surgical intervention may cease chronic uncontrolled seizures. ${ }^{[3]}$ However, there is a possibility that surgical intervention may have an adverse effect on cognitive functions. Considering the role of the temporal lobe in memory and language functions, the patients with left temporal lobe epilepsy may develop important cognitive problems after surgical intervention. It is reported that the most common cognitive dysfunction is related to memory and naming problems. ${ }^{[4-9]}$ These unfavorable cognitive changes may lead to many problems in the daily and professional lives of patients. Many patients suffer from cognitive impairment as one of the most severe and disabling outcomes of epilepsy. This cognitive disorder has significant effects on disability and quality of life. ${ }^{[10]}$

Cognitive rehabilitation (CR) is a program designed for working together with health professionals and individuals with cognitive impairment and their families, aiming to reduce functional impairments, increasing social activity and participation within the framework of personal goals and tailored approaches. One of the most important points of cognitive rehabilitation is the recovery of personal independence. ${ }^{[11,12]}$ Therefore, it is important to know whether epilepsy patients can be treated with the cognitive rehabilitation program. There are many studies on the type and extent of the cognitive deficits in patients with temporal lobe epilepsy before and after surgery. However, there are very few studies on the application of cognitive rehabilitation methods to improve cognitive problems and minimize their destructive effects. ${ }^{[13,14]}$ The results of these studies indicate the potential utilization of $\mathrm{CR}$ for patients with epilepsy ${ }^{[6]}$ In most of the studies investigating the effects of cognitive rehabilitation after epilepsy surgery, a wide range of rehabilitation techniques were used, either with methods not adequately described or without being standardized. In addition, few studies have addressed the results of the treatments and their practical applications to the patients' daily lives. ${ }^{[6,15,16]}$ In this study, we aimed to establish a protocol proposal for the rehabilitation of impaired cognitive functions after temporal lobe epilepsy surgery. For this purpose, two patients who developed cognitive problems after surgery are presented here to discuss the effects of the $C R$ program, which is focused on attention, memory and executive functions.

\section{Materials and Methods}

This study was conducted with two patients who underwent surgery at Istanbul University Cerahpasa Medical Faculty after being evaluated with a protocol applied to all epilepsy surgery candidates. They were referred to the CR outpatient clinic at Istanbul Medipol University Mega Hospital after epileptic surgery because of their cognitive problems.

\section{Case Report}

\section{Case 1}

A 37-year-old, law school graduate, lawyer, left-handed female patient had a history of smoking and no systemic disease other than epilepsy. There were no specific features regarding health issues in her personal and family history. The patient suffered from focal seizures related to the right temporal lobe, which became resistant to drugs despite different anti-epileptic drug combinations. Since her professional and social life was adversely affected due to more frequent and severe seizures, the patient was referred to surgical intervention in 2009. Presurgical evaluation with intracranial recordings (her MRI was normal) revealed right temporal epileptogenic area and she underwent tailored right temporal lobectomy. The patient was regularly followed up with neuropsychometric assessments. When the preoperative neuropsychological test results of the patient were evaluated, impairment in spontaneous retrieval performance and learning difficulties in both verbal and nonverbal memories were observed. The results of neuropsychological evaluation before surgery are shown in Table 1. Neuropsychometric assessment performed six months after surgery resulted in a mild improvement in all memory performances. By the assessment performed one year later, all cognitive functions were found to be normal except for mildly low performance in nonverbal memory. However, the memory complaints of the patient started in this period. In 2014, it was found that executive functions of the patient, such as response inhibition, verbal fluency and planning, were mildly affected. On the other hand, both verbal and nonverbal memories were moderately affected. By the neuropsychometric assessment performed in 2018, the patient was found to be affected by some executive 
functions, particularly in attention, response inhibition, and planning skills. When the cognitive flexibility skills were evaluated, the duration of interference was found to be prolonged, whereas abstraction and conceptualization skills deteriorated. Moreover, poor performance in overall memory evaluation, including instant recording, learning and free recall in both verbal and non-verbal memory, were also noted. While visual perceptual functions remained unchanged, her naming and visuo-constructive abilities were mildly affected. The patient complained that she had difficulty in finding proper words, especially in daily life conversations, and her non-fluent speech adversely affected her performance in professional life and discouraged her from attending social organizations. As a result, the patient was included in our rehabilitation program. The seizure frequency decreased remarkably after surgery, but she did not become completely seizure-free. Therefore, she continued on antiepileptic drugs. Before starting the rehabilitation program, the patient was being treated with Oxcarbazepine $600 \mathrm{mg}(3 \times 2)$, Clobazam $10 \mathrm{mg}(2 \times 1)$, Propranolol $\mathrm{HCl} 20 \mathrm{mg}(1 \times 1)$ and Sodium Valproate $500 \mathrm{mg}$ $(2 \times 1)$. After starting the $C R$, sodium valproate was discontinued. Instead, Topiramate $50 \mathrm{mg}(1 \times 1)$ was added to the medication. During the $\mathrm{CR}$, this was recorded as the only drug change.

\section{Case 2}

Case 2 was a 36-year-old, middle school graduate, unemployed, right-handed female patient. There were no specific features regarding health issues in her personal and family history. The patient suffered from left temporal lobe epilepsy due to mesial temporal sclerosis and underwent left anterior temporal lobectomy in 2013. She stayed on levetiracetam 1000 BID and carbamazepine 200 BID as she had few recurrent seizures. Evaluating the preoperative neuropsychological test results, it was determined that learning difficulty in verbal memory was forefront. In the postoperative period neuropsychological assessment results, the patient had difficulty in learning the verbal material, difficulty in focusing and sustaining attention. On the other hand, she developed an occasional difficulty in remembering faces and recognising people with retrograde amnesia, including her age of 14 and the period after. The patient experienced difficulty in reading and writing and had difficulty in even basic arithmetic skills. The patient complained that she used to suffer from different communication problems in daily living activities, including troubles with her family members as well. These communication problems affected her professional life and caused her to avoid working.

\section{Neuropsychological assessment}

Patients included in this study were evaluated in detail before and after the CR process with a neuropsychometric test battery. The following tests were applied: Forward and Backward Digit Span Test, Verbal Fluency Tests, Stroop Test, Proverbs and Bilateral Similarities Sub-Tests for attention and executive functions; Verbal Memory Processes Test (SBST) for verbal memory; WMS Logical Memory Subtest for logical memory; WMS Visual Memory Subtest for nonverbal memory; Benton Facial Recognition Test, Figure and Shape Copying Test for visual-spatial functions; Boston Naming Test for language functions. Besides these tests, the Beck Depression Inventory was also applied to evaluate behavioural symptoms. ${ }^{[17-20]}$

\section{Rehabilitation program}

The implemented CR program aims to strengthen the compensatory and adaptation strategies and to improve the memory and executive functions to overcome and/or cope with the cognitive deficits that may occur after the surgery. The program is designed as a holistic approach.

The sessions were conducted for six months, as 60 minutes sessions per week. A six-step program was organized. Sessions were held to establish the preserved abilities of patient, while the exercise parameters were adjusted accordingly to the cognitive/intellectual level of the patient. When the patient achieved $90 \%$ accuracy on a given task, the task was made more difficult. The main purpose was to retrain the impaired cognitive function and transfer the strategies learned in the sessions to daily life (Annex 1).

The first step was to determine the complaints and needs of the patient by making a general assessment. Additionally, the patient was informed about the compensatory methods, including the external aids and the environmental adaptation. Consequently, the patient was shown how to use these methods properly, such as calendar, agenda, alarm, reminder notes and keeping a diary. Other steps addressed attention, memory, visuospatial perception and executive functions, respectively. In addition, phone/computer games were used and homework assignments were given every week to transfer the strategies taught in the $C R$ sessions to daily living activities. The targeted goals and exercises at each step are shown in Annex 1. 
Annex 1. Rehabilitation protocol

\begin{tabular}{|c|c|c|}
\hline & Goal & Task \\
\hline \multirow[t]{3}{*}{$1^{\text {st }}$ STEP } & \multirow{3}{*}{$\begin{array}{l}\text { Determining the patient's } \\
\text { problems, complaints and } \\
\text { needs } \\
\text { Utilizing compensatory } \\
\text { techniques, environmental } \\
\text { adaptations }\end{array}$} & $\begin{array}{l}\text { Determining functional status, physical and emotional level, cognitive skills } \\
\text { and communication skills }\end{array}$ \\
\hline & & Utilizing tools, such as calendar, agenda, alarm, reminder, diary and notepad, \\
\hline & & and writing homework in every session \\
\hline \multirow[t]{10}{*}{$2^{\text {nd }} S T E P$} & \multirow{2}{*}{$\begin{array}{l}\text { Increasing the attention } \\
\text { function }\end{array}$} & Forward/backward rhythmic counting \\
\hline & & Determining the number of words in a paragraph \\
\hline & \multirow{8}{*}{$\begin{array}{l}\text { Visual memory attention } \\
\text { exercises }\end{array}$} & Spelling the letters of a word forwardly and backwardly \\
\hline & & Mental arithmetic for four operations \\
\hline & & $\begin{array}{l}\text { Details of the caricaturized visuals and real photos without looking at the } \\
\text { picture and looking at the description }\end{array}$ \\
\hline & & $\begin{array}{l}\text { Describing the details of the caricaturized images and photographs by } \\
\text { looking at the visual image }\end{array}$ \\
\hline & & Mental arithmetic for four operations \\
\hline & & $\begin{array}{l}\text { Describing the details of the caricaturized images and photographs from } \\
\text { memory after looking at the visual image }\end{array}$ \\
\hline & & $\begin{array}{l}\text { Creating a story with the abstraction on picture, and reconciling the story } \\
\text { created with real life }\end{array}$ \\
\hline & & $\begin{array}{l}\text { Functional visual attention exercises in various indoor and exterior spaces } \\
\text { (e.g., home, hospital, road and street) }\end{array}$ \\
\hline \multirow[t]{8}{*}{$3^{\text {rd }}$ STEP } & $\begin{array}{l}\text { Improving memory } \\
\text { function }\end{array}$ & $\begin{array}{l}\text { Visual memory: teaching visual description and associating a physical feature } \\
\text { with a person's name in concern with the naming memory }\end{array}$ \\
\hline & \multirow[t]{7}{*}{$\begin{array}{l}\text { Teaching of memory } \\
\text { strategies (internal/ } \\
\text { external strategies) }\end{array}$} & $\begin{array}{l}\text { Recalling various human pictures with their names after examining 1-2 } \\
\text { minutes (short and long-term recall) (number of pictures should be increased } \\
\text { in line with the success of the patient) }\end{array}$ \\
\hline & & $\begin{array}{l}\text { After showing complex figures, shapes are closed; drawing the figures in } \\
\text { short-term and long-term periods }\end{array}$ \\
\hline & & $\begin{array}{l}\text { Asking the patients to make up a story through showing various pictures, and } \\
\text { asking them to repeat the same story in the next session (after one week) (the } \\
\text { number of people involved in the stories gradually is increased starting from } \\
\text { one individual) }\end{array}$ \\
\hline & & $\begin{array}{l}\text { Verbal Memory: vocabulary recall exercises, starting from } 10 \text { words up to } 15 \\
\text { words, and trying to recall these words both in short and long term periods }\end{array}$ \\
\hline & & $\begin{array}{l}\text { In the event of aphasia seen like in Case-2, working with cards, naming } \\
\text { exercises with cards (e.g., colors, vegetable-fruit and animal naming), filling } \\
\text { gaps in Turkish texts, and question-answer exercises }\end{array}$ \\
\hline & & $\begin{array}{l}\text { Logical Memory: Asking to read stories in various lengths and asking to } \\
\text { narrate them in detail, asking the open-ended/yes-no/right-wrong questions } \\
\text { about the stories (re-narrating the stories both in short and long term periods, } \\
\text { repeating them in the immediate following week's session) }\end{array}$ \\
\hline & & $\begin{array}{l}\text { Reading a paragraph in a newspaper, and conveying all major arguments } \\
\text { without looking at the paragraph; answering questions about the paragraph } \\
\text { after doing other cognitive exercises non-related to the before-mentioned } \\
\text { paragraph after } 15 \text { minutes }\end{array}$ \\
\hline
\end{tabular}


Annex 1. Rehabilitation protocol (continuation)

\begin{tabular}{|c|c|c|}
\hline & Goal & Task \\
\hline \multirow[t]{7}{*}{$4^{\text {th }}$ STEP } & \multirow{7}{*}{$\begin{array}{l}\text { Developing the skills of } \\
\text { visuospatial perception and } \\
\text { shape copying }\end{array}$} & $\begin{array}{l}\text { Copying shapes starting from simple shapes towards complex three- } \\
\text { dimensional figures }\end{array}$ \\
\hline & & Exercising with pen and paper for direction concept \\
\hline & & $\begin{array}{l}\text { Giving functional diverse tasks regarding finding place and directions, finding } \\
\text { rooms in hospitals, and walking on the road }\end{array}$ \\
\hline & & $\begin{array}{l}\text { Perceiving of various images (estimating the whole from the part and } \\
\text { inferring the whole from the part) }\end{array}$ \\
\hline & & Naming/Explaining pictures on working cards \\
\hline & & $\begin{array}{l}\text { Practising of colors with various materials (coloring book, mysterious garden } \\
\text { coloring book, mandala coloring book) }\end{array}$ \\
\hline & & Colouring different shapes in complex figures with a specific color \\
\hline \multirow[t]{17}{*}{$5^{\text {th }}$ STEP } & \multirow{17}{*}{$\begin{array}{l}\text { Improving/strengthening } \\
\text { executive functions }\end{array}$} & Verbal Fluency: Listing words that are evocative of concrete words \\
\hline & & Listing words that are evocative of abstract words \\
\hline & & $\begin{array}{l}\text { Describing the visual imagery of a place (e.g., Think about a school, now you're } \\
\text { in the canteen and tell me what you remember or see in your imagination) }\end{array}$ \\
\hline & & Finding the link between two words (e.g., school-toast) \\
\hline & & Giving clues regarding a word and asking to guess what the word is \\
\hline & & $\begin{array}{l}\text { Completion of a story, re-narrating the story without using the same words } \\
\text { (using synonyms and/or similar words) }\end{array}$ \\
\hline & & Creating a case scenario \\
\hline & & Finding synonyms and antonyms \\
\hline & & Explaining the meanings of words \\
\hline & & Producing words composed of specific syllables \\
\hline & & Finding out a thought and the source of that thought \\
\hline & & Listing words in line with the category \\
\hline & & Finding similarity and differences among words \\
\hline & & $\begin{array}{l}\text { Abstraction/Imagination Exercises: Proverb description, clock drawing, closed } \\
\text { eyes imagination and verbal expression }\end{array}$ \\
\hline & & $\begin{array}{l}\text { Planning, Problem Solving: Making up the appropriate route, time schedule, } \\
\text { and weekly programs in line with given instructions }\end{array}$ \\
\hline & & Making up new plans for various problems \\
\hline & & $\begin{array}{l}\text { Practising pen and paper exercises containing multiple instructions at the } \\
\text { same time }\end{array}$ \\
\hline \multirow[t]{9}{*}{$6^{\text {th }}$ STEP } & Practicing of strategies & Pen and paper exercises \\
\hline & routinely in home and & Practising with multiplication table \\
\hline & community environments & Recitating of verses from various poems \\
\hline & through with help of & Extracting of summary of a book \\
\hline & homework, phone and & Doing activities, such as crossword puzzle and sudoku \\
\hline & computer games & Playing vocabulary games like Scrabble \\
\hline & Transferring of the strategies & Repeating the following day's plan from one night before \\
\hline & taught in the CR program to & Doing housework, cooking and making new recipes \\
\hline & daily life & Calculating the number of beads, abacus exercises \\
\hline
\end{tabular}




\section{Results}

The results of neuropsychometric tests before and after CR are displayed in the table (Table 1).

Considering the results of neuropsychometric assessment, there was an improvement in the frontal functions of the case- 1 , particularly concerning complex attention, sustained attention and verbal fluency. The findings showed that there was a certain level of progress in cognitive flexibility skills and in abstraction and conceptualization skills. It was found that instant recording; learning and spontaneous retrieval performance increased in the memory assessment tests. However, moderate improvement was observed in visual perceptual functions, naming and visuo-constructive skills. All cognitive functions of the patient, who had problems in frontal and memory functions before rehabilitation, reached normal limits after the cognitive rehabilitation. Concerning the patient's self-as- sessment, she stated that she was not struggling to find words and was able to speak fluently after the CR program. By this means, the patient asserted that her performance both in her professional life and her social environment ameliorated.

Case-2 showed a significant improvement in logical, instant and long-term memory within the framework of the results of neuropsychometric assessment. In addition to the progression in cognitive flexibility skills, abstraction, conceptualization and naming skills, there was also a moderate improvement in her visual perceptual functions and visuo-constrictive skills. In the meantime, the depression score improved significantly as well. All cognitive functions of the patient, who had problems in frontal and memory functions before rehabilitation, attained normal limits after the CR. Communication problems with her family and social surroundings substantially disappeared after the rehabilitation sessions, and the patient started working again.

Table 1. The results of neuropsychometric tests

\begin{tabular}{|c|c|c|c|c|}
\hline & \multicolumn{2}{|c|}{ Case-1 } & \multicolumn{2}{|c|}{ Case-2 } \\
\hline & $\begin{array}{l}\text { Pre- } \\
\text { rehabilitation } \\
\text { (z) }\end{array}$ & $\begin{array}{l}\text { Post- } \\
\text { rehabilitation } \\
\text { (z) }\end{array}$ & $\begin{array}{c}\text { Pre- } \\
\text { rehabilitation } \\
\text { (z) }\end{array}$ & $\begin{array}{l}\text { Post- } \\
\text { rehabilitation } \\
\text { (z) }\end{array}$ \\
\hline Personal and actual information & 6 & 6 & 4 & 4 \\
\hline Orientation & 5 & 4 & 4 & 4 \\
\hline Mental control (Months backward) (second) & 41 & 16 & $53 / 1$ & $35 / 2$ \\
\hline $\begin{array}{l}\text { Mental control (Counting starting from } 1 \text { by } \\
\text { increasing 3) (second) }\end{array}$ & 40 & 29 & $9 / 2$ & 46 \\
\hline Forward Digit Span Test & 5 & 5 & 3 & 3 \\
\hline Backward Digit Span Test & 4 & 4 & 3 & 3 \\
\hline Verbal Fluency Test & $9(-1)$ & $10(+0)$ & $6(-2)$ & $8(-1)$ \\
\hline Animal counting & $18(-1.8)$ & $19(-1.6)$ & $15(-2.25)$ & $14(-2.50)$ \\
\hline KAS (Total score) & $42(-0.81)$ & $41(-0.90)$ & $33(-0.60)$ & $33(-0.60)$ \\
\hline Boston Naming Test (Spontaneously) & 24 & 27 & 18 & 18 \\
\hline Stroop Test (second) & $104(-5.81)$ & $97(-5.18)$ & $28(+1)$ & $17(+2)$ \\
\hline Clock orawing & 1 & 2 & 3 & 4 \\
\hline WMS (Visual Short Term Memory) & $10(-0.68)$ & $12(+0.10)$ & $11(-0.28)$ & $14(+0.89)$ \\
\hline WMS (Visual Long Term Memory) & $8(-1.10)$ & $12(+0.24)$ & $13(+0.58)$ & $13(+0.58)$ \\
\hline WMS (Logical Short Term Memory) & $17(+0.28)$ & $17(+0.28)$ & $2(-4.33)$ & $14(-0.64)$ \\
\hline WMS (Logical Long Term Memory) & $19(+0.79)$ & $22(+1.76)$ & $3(-4.36)$ & $11(-1.78)$ \\
\hline SBST-Immediate & $6(-0.91)$ & $6(-0.91)$ & $2(-2.86)$ & $5(-1.40)$ \\
\hline SBST-Total & $103(-2.65)$ & $117(-1.33)$ & $66(-6.14)$ & $86(-4.26)$ \\
\hline SBST-Long Term Memory & $11(-2.85)$ & $15(+0.95)$ & $8(-5.71)$ & $7(-6.66)$ \\
\hline SBST-Delay Recognition & $4(-2.91)$ & $9(-7.72)$ & $7(-5.79)$ & $8(-6.75)$ \\
\hline Benton Facial Recognition Test (Short Form) & $22(-0.11)$ & $26(+1.69)$ & $22(+0.32)$ & $21(-0.08)$ \\
\hline Beck Depression Inventory & NA & 17 & 14 & 5 \\
\hline
\end{tabular}




\section{Discussion}

In our study, we present the effects of our cognitive rehabilitation program for patients experiencing cognitive problems after temporal lobe epilepsy surgery in two cases. Our protocol consists of a comprehensive multimodal program, primarily focusing on the cognitive abilities of patients. Our ultimate goal is to alleviate the cognitive problems experienced after epilepsy surgery and to improve the quality of life of individuals. Various CR programs are applied for the cognitive disorders that may occur after epilepsy surgery. ${ }^{[6]}$ However, the existing programs emphasize memory, which is the most frequently affected cognitive function after surgery. ${ }^{[13]}$ On the other hand, our study primarily reveals the cognitive profile of patients with a detailed neuropsychometric assessment, and then focuses on the improvement of all cognitive abilities within the framework of the patient's needs and requests. In this respect, CR is carried out with personalized exercises for attention, memory and executive functions.

Studies have shown that patients with temporal lobe epilepsy experience attention and memory problems after surgery. ${ }^{[4,8,9]} A$ healthy network of attention is a prerequisite for a higher-level of cognitive functions, such as memory and executive functions. ${ }^{[21,22]}$ Thus, the exercises regarding attention function were performed in each session to improve this cognitive skill. During the sessions, there was a noticeable improvement in their attention functions, which the patients also noticed themselves. In the neuropsychological assessments performed after the sessions, an evidence-based improvement in the attention function in both patients was obtained. When the literature is reviewed, it is understood that many strategies are used to improve the memory performance of the patients (such as cognitive strategies and compensatory techniques). ${ }^{[23]}$ Having worked on a heterogeneous group of epileptics, Schefft et al. report that patients perform better in memory testing following the implementation of active cognitive strategies. ${ }^{[24]}$ Koorenhof et al. ${ }^{[14]}$ emphasize that external memory supports may be useful. There are also approaches asserting that active learning can be more useful in solving memory problems when supported by external assistance. ${ }^{[25]}$ In our sessions devoted to memory function, the active cognitive rehabilitation strategies were taught to the patients, and exercises were made to practice these strategies. Patients were encouraged to benefit from compensatory techniques as well, not to be limited solely to active strategies, to increase their quality of life. Although our findings could not compare active and compulsive memory strategies, they broadly support the effectiveness of memory rehabilitation techniques. There are also several approaches to relieve memory disorders in epileptic individuals. Some studies focus on one type of cognitive strategy. ${ }^{[26]}$ One study reports that patients with left temporal lobe epilepsy use semantic coding, while right temporal lobe epilepsy patients benefit from more retrieval strategies. ${ }^{[27]}$ The cognitive strategies in our program were chosen from the methods that were found to be effective in the previous studies. In our sessions, there was no focus on a single strategy and no distinction was made for the lateralization of the patients as well. Verbal, visual and logical memory functions of our patients ameliorated after the rehabilitation program. A study, showing that cognitive rehabilitation improves the decline in verbal memory seen after temporal lobe resection, reports that the surgical field is determinant on verbal learning and recognition. In the same study, patients with left temporal lobe resection had less progress in their verbal memory after rehabilitation compared to patients with right temporal lobe resection. ${ }^{[4]}$ In our study, a better improvement was also acquired in the verbal memory of the patient with right temporal lobe resection. In accordance with the literature, it is suggested that the verbal memory capacity will benefit less from cognitive rehabilitation after the left side epileptic surgery. ${ }^{[4]}$

In this respect, it is thought that the result of the post-rehabilitation neuropsychometric test of our patient with right temporal lobe resection is better probably due to the resection area. ${ }^{[28]}$ In epilepsy surgery, clinically, the utmost problems arise from after the left temporal lobe resection. It has been reported that $44 \%$ of the patients with left temporal lobe resection and only $20 \%$ of the patients with right temporal lobe resection experience impaired verbal memory. In addition, $34 \%$ of the patients with left temporal lobe surgery have problems in naming skills. ${ }^{[6]}$ The severe problem after the left temporal lobe resection may cause worse post-rehabilitation performance. In addition, it is also assumed that the human brain develops a functional reserve to be able to cope with neuronal loss and that the brain has a reserve capacity accordingly. Studies have shown that plasticity is less in patients with left temporal lobe epilepsy. ${ }^{[28,29]}$ On the other hand, it should be kept in mind that the level of education of our right temporal lobe epileptic patient is higher. It 
is claimed that higher education is associated with a higher reserve against cognitive impairment. ${ }^{[28]}$ Although our left temporal lobe epileptic patient did not fully reflect her recovery during the test, she managed to get back to professional life and to transfer the strategies successfully to her daily living activities after the cognitive rehabilitation program. Both of our patients confirmed their improvements in cognitive skills according to their subjective assessments. Moreover, previous studies with epileptic patients indicate that subjective assessments of the patients for memory problems are not highly correlated with the objective memory tests and the standard neuropsychological tests. ${ }^{[30]}$

The participants were given various assignments to apply for the training program routinely in their daily lives. The activities to improve memory, such as crossword puzzles and sudoku, were added to the daily tasks of patients. ${ }^{[25]}$ Homework assignments had positive effects on their daily lives according to the subjective assessments of the patients.

Anxiety and depression are important findings to be considered in memory function rehabilitation. In a study, the frequency of daily memory problems decreased with the decline of depression score in patients with left temporal lobe epilepsy. ${ }^{[6,14]}$ In our study, a significant improvement was obtained in the depression score of the patient with left temporal lobe epilepsy. The pre-rehabilitation depression score of our patient with right temporal lobe epilepsy was not determined, but it was observed that post-rehabilitation depression used to continue moderately.

There is controversy in the rehabilitation process regarding how long after the surgery, the rehabilitation should start and how long the sessions should last. In our study, the patient with the left temporal lobe resection started the CR program one year later after the surgery, while the patient with the right temporal lobe resection started the rehab program nine years after the surgery. In the process of just before starting the $C R$, it was observed that the problems experienced by the patients on cognitive functions increased. As a result, with the conformity of their neuropsychometric reports, the patients were included in the CR program. Patients with left temporal lobe resection are thought to experience a faster decline. There is a need for studies on how long after the surgery, the rehabilitation should be started. It is thought that regularly implemented rehabilitation will be more effective. We performed our sessions once a week for six months.
The studies are organized as 4, 6 or 12 weeks sessions. One limitation of our study was that we repeated the neuropsychometric assessment one week after the completion of the CR program. In some studies, follow-ups are performed with one-month period terms after the rehabilitation. ${ }^{[6]}$ For the evaluation of longer continuous effects, it is necessary to determine the ideal duration of the CR program.

Both therapeutic and functional approaches can be used in the clinic. These approaches may be simultaneous or can be used one after the other. Rehabilitation strategies should be determined in conformity with the educational level, socio-cultural/economic level, profession, daily life priorities and needs of the patient. Strategies can be adapted in accordance with the patient's occupation, lifestyle, in short, the patient's daily activities. ${ }^{[12]}$ The last point we would like to emphasize is that a personalized rehabilitation approach should be applied using different approaches for different cognitive disorders.

Although the results have been obtained with two patients, our results show that cognitive rehabilitation has a significant and positive effect on epileptic patients who have postoperative attention, memory and executive function problems. Nevertheless, it would be ideal for future studies to standardize the rehabilitation program for postoperative epileptic patients and to demonstrate the short and long-term impacts of cognitive rehabilitation on an evidence-based basis with larger participants.

\section{Ethics Committee Approval}

Ethics committee approved.

\section{Informed Consent}

Informed consents of patients were received.

\section{Peer-review}

Externally peer-reviewed.

\section{Conflict of interest}

The authors declare that they have no conflict of interest.

\section{Authorship Contributions}

Concept: M.S., L.H.; Design: M.S., Ö.E.O.; Supervision: Ç.Ö., L.H.; Materials: M.S.; Data collection \&/or processing: M.S.; Analysis and/or interpretation: M.S., L.H.; Literature search: M.S., L.H.; Writing: M.S., Ö.E.O.; Critical review: Ç.Ö., L.H.

\section{References}

1. Bilginer B, Akalan N. Temporal Lob Epilepsileri. Türk Nöroşirürji Dergisi 2006;16(3):156-9. 
2. Elger $C E$, Schmidt D. Modern management of epilepsy: a practical approach. Epilepsy Behav 2008;12(4):501-39. [CrossRef]

3. Ozkara C, Uzan M, Benbir G, Yeni N, Oz B, Hanoğlu L, et al. Surgical outcome of patients with mesial temporal lobe epilepsy related to hippocampal sclerosis. Epilepsia 2008;49(4):696-9.

4. Helmstaedter C, Loer B, Wohlfahrt R, Hammen A, Saar J, Steinhoff $B J$, et al. The effects of cognitive rehabilitation on memory outcome after temporal lobe epilepsy surgery. Epilepsy Behav 2008;12(3):402-9. [CrossRef]

5. Hanoğlu L, Ozkara C, Keskinkiliç C, Altin U, Uzan M, Tuzgen S, et al. Correlation between $1 \mathrm{H}$ MRS and memory before and after surgery in mesial temporal lobe epilepsy with hippocampal sclerosis. Epilepsia 2004;45(6):632-40. [CrossRef]

6. Mazur-Mosiewicz A, Carlson HL, Hartwick C, Dykeman J, Lenders $\mathrm{T}$, Brooks BL, et al. Effectiveness of cognitive rehabilitation following epilepsy surgery: Current state of knowledge. Epilepsia 2015;56(5):735-44. [CrossRef]

7. Gleissner U, Helmstaedter C, Schramm J, Elger CE. Memory outcome after selective amygdalohippocampectomy: a study in 140 patients with temporal lobe epilepsy. Epilepsia 2002;43(1):87-95. [CrossRef]

8. Sherman EM, Wiebe S, Fay-McClymont TB, Tellez-Zenteno J, Metcalfe A, Hernandez-Ronquillo $L$, et al. Neuropsychological outcomes after epilepsy surgery: systematic review and pooled estimates. Epilepsia 2011;52(5):857-69. [CrossRef]

9. von Rhein $B$, Nelles $M$, Urbach $H$, Von Lehe $M$, Schramm J, Helmstaedter $C$. Neuropsychological outcome after selective amygdalohippocampectomy: subtemporal versus transsylvian approach. J Neurol Neurosurg Psychiatry 2012;83(9):887-93.

10. Giovagnoli AR, Parente A, Tarallo A, Casazza M, Franceschetti S, Avanzini G. Self-rated and assessed cognitive functions in epilepsy: impact on quality of life. Epilepsy Res 2014;108(8):14618. [CrossRef]

11. Cicerone KD, Dahlberg C, Kalmar K, Langenbahn DM, Malec $\mathrm{JF}$, Bergquist TF, et al. Evidence-based cognitive rehabilitation: recommendations for clinical practice. Arch Phys Med Rehabil 2000;81(12):1596-615. [CrossRef]

12. Oğul EÖ. Nörolojik Hastalıklarda Fizyoterapi ve Rehabilitasyon. Türkiye Klinikleri 2018:65-70.

13. Mosca C, Zoubrinetzy R, Baciu M, Aguilar L, Minotti L, Kahane $P$, et al. Rehabilitation of verbal memory by means of preserved nonverbal memory abilities after epilepsy surgery. Epilepsy Behav Case Rep 2014;2:167-73. [CrossRef]

14. Koorenhof L, Baxendale S, Smith N, Thompson P. Memory rehabilitation and brain training for surgical temporal lobe epilepsy patients: a preliminary report. Seizure 2012;21(3):178-82.

15. Farina E, Raglio A, Giovagnoli AR. Cognitive rehabilitation in ep- ilepsy: An evidence-based review. Epilepsy Res 2015;109:2108. [CrossRef]

16. Barr W. Cognitive Rehabilitation for Epilepsy: What Do We Really Know? Epilepsy Curr 2016;16(2):87-8. [CrossRef]

17. Karakaş S. Türk kültürü için standardizasyonu yapılmış nöropsikolojik testler topluluğu: BiLNOT Bataryası 1996. 32. Ulusal Nöroloji Kongresi Kitabı; 1996. p. 43-70.

18. Öktem Ö. Sözel bellek süreçleri testi (bir ön calışma). 1992. p. 196-206.

19. Soylu Ekinci A, Cangöz B. Boston Adlandırma Testinin Türk Yaşlı Örneklemi İçin Uyarlama ve Norm Belirleme Çalışması. Nöropsikiyatri Arşivi 2018;55:341-8.

20. Hisli N. Beck Depresyon Envanterinin üniversite öğrencileri için geçerliği, güvenirliği. Psikol Derg 1989;6(23):3-13.

21. Schoenberg MR, Scott JG. The Little Black Book of Neuropsychology A Syndrome-Based Approach 2011. p. 968. [CrossRef]

22. Stuss DT, Winocur G, Robertson IH. Cognitive Neurorehabilitation Evidence and Application. 2nd ed. Cambridge Med 2010. p. 606.

23. Del Felice A, Alderighi $M$, Martinato $M$, Grisafi D, Bosco A, Thompson PJ, et al. Memory Rehabilitation Strategies in Nonsurgical Temporal Lobe Epilepsy: A Review. Am J Phys Med Rehabil 2017;96(7):506-14. [CrossRef]

24. Schefft BK, Dulay MF, Fargo JD, Szaflarski JP, Yeh HS, Privitera $M D$. The use of self-generation procedures facilitates verbal memory in individuals with seizure disorders. Epilepsy Behav 2008;13(1):162-8. [CrossRef]

25. Thompson PJ, Conn H, Baxendale SA, Donnachie E, McGrath K, Geraldi $C$, et al. Optimizing memory function in temporal lobe epilepsy. Seizure 2016;38:68-74. [CrossRef]

26. Jones MK. Imagery as a mnemonic aid after left temporal lobectomy: contrast between material specific and generalised memory disorders. Neuropsychologica 1974;12:21-4. [CrossRef]

27. Bresson C, Lespinet-Najib V, Rougier A, Claverie B, N'Kaoua B. Verbal memory compensation: application to left and right temporal lobe epileptic patients. Brain Lang 2007;102(1):1321. [CrossRef]

28. Köylü B, Walser G, Ischebeck A, Ortler M, Benke T. Functional imaging of semantic memory predicts postoperative episodic memory functions in chronic temporal lobe epilepsy. Brain Res 2008;1223:73-81. [CrossRef]

29. Jokeit $H$, Ebner A. Effects of chronic epilepsy on intellectual functions. Prog Brain Res 2002;135:455-63. [CrossRef]

30. Elixhauser A, Leidy NK, Meador K, Means E, Willian MK. The relationship between memory performance, perceived cognitive function, and mood in patients with epilepsy. Epilepsy Res 1999;37:13-24. [CrossRef] 